\title{
Impact of Gross Capital Formation and Foreign Direct Investment on Economic Growth in Rwanda (1990-2017)
}

\author{
Jean Marie Vianney Ntamwiza, Fabien Masengesho \\ Department of Civil Engineering, Rwanda Polytechnic, Kigali, Rwanda \\ Email: ntamwizajeanmarie@gmail.com
}

How to cite this paper: Ntamwiza, J. M. V., \& Masengesho, F. (2022). Impact of Gross Capital Formation and Foreign Direct Investment on Economic Growth in Rwanda (1990-2017). Current Urban Studies, 10, 1-13. https://doi.org/10.4236/cus.2022.101001

Received: July 14, 2021

Accepted: January 7, 2022

Published: January 10, 2022

Copyright $\odot 2022$ by author(s) and Scientific Research Publishing Inc. This work is licensed under the Creative Commons Attribution International License (CC BY 4.0).

http://creativecommons.org/licenses/by/4.0/

\section{(c) (i) Open Access}

\begin{abstract}
This study investigates the determinant of economic growth in Rwanda, using time series data for the period 1990-2017. These data have been analyzed and interpreted using statistical, analytical, synthetic methods as well as an econometrical approach. The economy of Rwanda represents the research gap about the components and determinants of economic growth as instrument policies to alleviate poverty and rise out production. The objective was to test the trends and relationship between capital formation, foreign direct investment and economic growth in Rwanda. This research tested and confirmed the following: gross capital formation and foreign direct investment are the main determinants of economic growth in Rwanda for the period under study. R-square, the overall measure of goodness of fit indicates that the explanatory variables included in the above model explain $89.3 \%$ of the variation of the dependent variable (GDP growth) for the long run regression model and 97\% for the error correction model. The error correction model shows that the speed back to equilibrium is $86.4 \%$ that is when a shock happens in the previous period it decreases by $86 \%$ in the current period. This indicates that there is a significant short-run relationship as it was shown by the coefficients of the error correction model which are significant. Based on the existence of a longrun co-integrating relationship and the short-run interactions, the researcher tested and confirmed that there was a short-run and long-run positive relationship between capital formation, foreign direct investment and economic growth in Rwanda during the research period. The study reveals that capital formation has a significant positive effect on gross domestic product in the long run. The policy-makers should formulate policies by looking at the determinants of growth as they are crucial in the process of economic growth and have a positive remarkable role in the economic acceleration.
\end{abstract}




\section{Keywords}

Economic Growth, Gross Capital Formation, Foreign Direct Investment, Inflation and Exchange Rate

\section{Introduction}

Rwanda is one of the Sub-Saharan East Africa nations; it is a developing country with a higher density of population among Sub-Saharan African countries and is landlocked with few natural resources and low levels of industrialization. The services sector contributed $47 \%$ of GDP while the agriculture sector contributed $31 \%$ to the GDP; the industry sector contributed $15 \%$ to the GDP while 7\% growth was attributed to adjustment for taxes and subsidies on products (NISR, 2018).

Economies are classified into two categories depending on the level of development, the level of living standards, the socio-political structure and the state of infrastructures. Some economies are said to be developed while others are less developed or developing (Boskin \& Lau, 1990).

In developing economies, more people are less or not skilled and are engaged in subsistence agriculture, their productivity is relatively lower which leads to a low level of living standard, poor socio-political structure and low level of infrastructure while more people in developed economies are skilled and are employed in off-farm activities where their marginal productivity is high which leads to a high level of living standard, effective and stable socio-political structure and higher level of infrastructure.

Rwanda is a developing country, and it has been experiencing an excess of imports over exports leading to a persistent budget deficit (Simbi, 2019). The severity of deficit increases the debt level of a country and reduces its capacity to finance development project due to heavy debt repayment. Rwandan economy can be discussed in two phases, a pre-genocide phase that is the period before the 1994 Tutsi Genocide and post-Tutsi genocide phase or the period after the Tutsi genocide.

During the pre-Tutsi genocide phase, Rwandan economy was characterized by a low level of living standard, poor socio-political structure and low level of infrastructure. Rwandan economy started from scratch after the 1994 Tutsi genocide, everything was destroyed by the genocide.

The country started with the ambition of reconstruction and stabilization. Decision-makers or economic policy-makers have tried to set national priorities, decisions and policies leading to tempting economic growth through economic recovery intending to move the country from those with low income to the middle-income countries (MINECOFIN, 2012). Rwanda's long-term vision, as inspired by its "Vision 2020", is to reduce the number of people living below the poverty line from $60 \%$ to $25 \%$ and to raise per capita incomes from $\$ 250$ to above $\$ 1000$. The Rwandan government has become very interested in microfinance and 
recognizes that a strong sector is crucial to meet their Poverty Reduction Strategy Paper (PRSP) development goals. Optimism over the role of microfinance as a poverty reduction intervention in Rwanda is increasing.

Trade is considered to have played a key role in building peace and reconciliation as Rwanda continues to recover from the genocide. For Rwanda to achieve all its development programs there is a need to evaluate the contribution of Gross Capital formation, and foreign direct investment on Rwandan economic growth. Rwanda experienced a low level of foreign direct investment during the period of ninety's due to the political environment which was not favorable for investors.

Since the last decade, the country formulated policies which encourage investors to invest in Rwanda. The aim of the country is to become a middle-income country by 2035 and higher-income country by 2050 (MINECOFIN, 2017; MINECOFIN, 2020). To become a middle-income country by 2035 requires achieving the annual average growth rate of $9.01 \%$ over the period of the national strategy for transformation one (2018-2024). Researches on the role of gross capital formation and foreign direct investment on economic growth are scarce in literature. Such gaps occurred specifically in a country like Rwanda which faced Genocide, there is a need to do such research and bridge the gap.

This paper is organized as follow, in the next section there is materials and methodology, section three is the research findings, and section four present the discussion, conclusion and policy recommendations.

\section{Literature Review}

Bruno et al. analyzed the impact of foreign direct investment in Rwanda for the period of 1970-2010. The result of their studies showed that FDI respond to change of GDP with one lag. A study conducted on the impact of foreign direct investment on economic growth in the economic community of western Africa states by PA Adamu and DE Oriakhi in 2013 for the period of 2000-2009 show a positive relationship between FDI and economic growth (Adamu \& Oriakhi, 2013). According to Eltis (2000), economic growth is resulted from the reinvested economic surplus or the excess of profit over cost. When the reinvested portion of the surplus is high, economic growth is more likely to be high.

An increase of government investment in better road network may reduce the costs of construction of a new factory by the private sector and reduce the transportation cost of heavy equipment (Boopen \& Khadaroo, 2008). Economists often look at the growth gross domestic product and the level of infrastructure to determine the mood of businesses within a nation. Stable business investment indicates a cycle peak, while lower business investment can signal economic contraction. Government investment in macroeconomics is a bit less important in a free market economy when compared to business investment (Barro, 1990). Higher government investment coupled with lower business investment, therefore, may signal a change in macroeconomic policy (Ndugbu, 2017).

According to Tayebwa (2000), Economic growth refers to a continuous rise of 
the volume of goods and services produced in an economy in a period of time. To determine whether economy is growing or declining, the total value of goods and services produced is constantly monitored and measured by relevant government departments.

Gross national product can be used to evaluate whether a nation's economy is heavily dependent on foreign earnings (Mankiw, 2003). When a country is highly depending on foreign earning, its inflows in terms of grant and foreign direct investment are very high leading to a negative net transfer of fund in the end. According to Mallakh (1969), an empirical study of the impact of capital formation on economic growth demonstrated a positive relationship in Libya. Above literatures indicate that FDI and Gross capital formation have a big role on economic growth. This research intends to analyze the role of FDI and GCF on economy of Rwanda, a country which needs to build more infrastructures, improve services to attract investors so that there can be a reduction of the gap between imports and exports.

\section{Materials and Methodology}

\subsection{Materials}

The following materials are important, foreign direct investment, capital formation, inflation and exchange rate are crucial to determine economic growth based on other literatures. In this research the methods and tools used to collect are documentary and analytical where secondary data were collected from reading the reports and data of the World Bank, International monetary fund and different research papers. All computations are performed using Eviews9 software as technique of data analysis after being processed/organized in excel sheet. This study used the annual data from 1990 to 2017.The data will be constructed and collected from various secondary data sources such as National Bank of Rwanda and NISR. The use of time series requires the econometric tests, in order to clarify the relationship between studied variables.

\subsection{Methodology}

According to the national income identity, GDP growth is a function of consumption, investment, government spending and net export which is the difference between export and import.

$$
Y_{t}=f(C, I, G, N X)
$$

where: $Y$ is Gross Domestic Product at period $t, C$ is Private consumption expenditures, $I$ represent Private investment, $G$ represent Government spending on capital and consumption goods and services and $N X$ is the Net export (export minus import). Due to the availability of the data, the researcher decided to use the following explanatory variables: foreign direct investment, gross capital formation, inflation rate and exchange rate.

The long-run regression model is specified as follow: 


$$
\begin{aligned}
& \mathrm{GDP}=\mathrm{f}(\text { FDI, GROSS_CAPITAL_F, EXCHANGE, INFLATION_RATE }) \\
& \text { GDP }= \mathrm{C}(1)+\mathrm{C}(2) * \mathrm{FDI}+\mathrm{C}(3) * \text { GROSS_CAPITAL_FORM } \\
&+\mathrm{C}(4) * \text { EXCHANGE }+\mathrm{C}(5) * \text { INFLATION_RATE }
\end{aligned}
$$

where: $C(1), C(2), C(3), C(4)$ and $C(5)$ are the parameters of the model.

Based on the theories, the expected signs of slope coefficients in the model are as follow: foreign direct investments are gross capital formation are positively related to gross domestic product.

The correction model is specified as follow:

$$
\begin{aligned}
\text { DGDP }= & \text { C }(1)+C(2) * \text { DLOG_FDI }+\mathrm{C}(3) * \text { DLOG_GROSS_CAP } \\
& +\mathrm{C}(4) * \text { DLOG_EXCH }+\mathrm{C}(5) * \text { DINF_RATE }+\mathrm{C}(1) * \mathrm{U}(-1)
\end{aligned}
$$

where: $C(1), C(2), C(3), C(4), C(5)$ and $C(6)$ are the parameters of the model.

The coefficient $C(6)$ is the error correction coefficient.

The study uses Augmented Dickey Fuller and Engle Granger Tests to test the stationarity and cointegration. It also uses normality test, Correlogram, Ramsey rest test and stability test.

\section{Finings and Discussion}

\subsection{Stationarity Test}

The method of Augmented Dickey-Fuller (ADF) test was employed to conduct stationarity of all the variables included in the model. Gross domestic product, foreign direct investment and inflation rate were stationary at levels whereas gross capital formation and exchange rate were stationary at first difference. The results of stationarity are presented in Appendix Table A1.

\subsection{Result of Co-Integration Test}

After testing for stationarity accordingly, there should be a co-integration test as indicated by Engle and Granger (1987). The existence of co-integration between the variables means that there is a long run relationship between the variables. The co-integration test is performed using Engel and Granger test. The result of cointegration indicate that there is cointegrating relationship between the variables in the model since the Engle Granger calculated of -6.535957 is more negative than the Engle Granger critical -2.653401 , i.e., it is significant at $1 \%$ level of significance. The results are presented in Appendix Table A2.

\subsection{Result of the Linear Regression Model}

The following are the result of the long run regression model:

$$
\begin{aligned}
\text { GDP }= & 350.16+0.60 * \text { LOG_FDI }+2.30 * \text { LOG_GROSS_CAP } \\
\text { Prob } & (0.0009)(0.0000) \quad(0.0002) \\
& +0.50 * \text { LOG_EXCH }+0.20 * \text { INFLATION_RATE } \\
& (0.0422) \quad(0.0422)
\end{aligned}
$$

In this equation, all the estimates of the coefficients of the variables have the 
positive sign as it was expected based on the theories. The entire coefficient's calculated probability are less than the 5\% critical value, this indicate that there is a significant long run relationship between explanatory variables and the dependent variable (GDP growth). The coefficient 0.597754 indicate that, holding other variables constant an increase of FDI by one percent will lead to an increase of GDP growth by 0.6 in long run. This is significant at one percent since the probability calculated of 0.000 is less than p-critical of 0.01 . The coefficient 2.27776 indicates that increases of gross capital formation by one percent lead to an increase by 2.27776 in long run. This is significant at $1 \%$ level as the p-calculated of 0.0002 is less than the p-critical of 0.01 . The coefficient 0.501893 indicates that an increase of exchange rate by one percent leads to an increase of GDP by 0.501893 in long run. This is significant at $5 \%$ level because p-calculated of 0.0422 is less than 0.05 .

The coefficient 0.169646 indicates that when inflation rate is at its lowest level an increase of inflation rate by one percent leads to an increase of GDP by 0.169646 in the long run. This means that when inflation is much lower, its increase motivates producers due to a rise in the price level hence an increase of GDP. This is significant at $5 \%$ level because p-calculated of 0.0422 is less than 0.05 . R-square, the overall measure of goodness of fit indicates that the explanatory variables included in the above model explain $89.3 \%$ of the variation of the dependent variable (GDP growth). Regression results are presented in Appendix Table A3.

\subsection{Error Correction Models}

The short-run model coefficients measure the dynamics of the model, the ECM measures the speed of adjustment to the long run equilibrium which is taking place and the results are presented in Appendix Table A4.

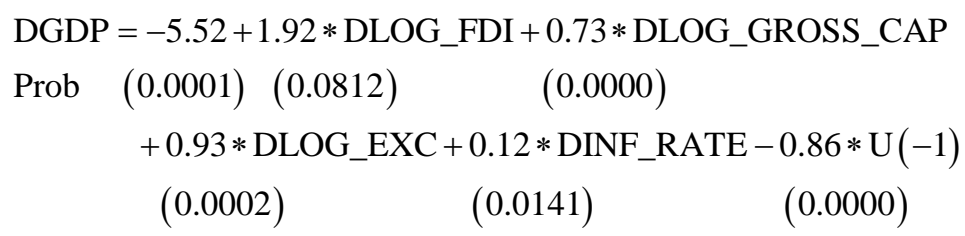

The negative coefficient of the error correction term $(-0.864952$.) is significant at level of $1 \%$, assuring that the co integration relationship between the included variables is valid. This indicates that, when chocks happen now in one year ahead it will be reduced by $86.4 \%$. It will take one year and three months for the growth to return to its initial trend. The error correction model demonstrates that this previous disequilibrium is progressively corrected in order to re-establish the long-run equilibrium situation among co integrating variables.

ECM presents the convergence of the model towards equilibrium by its negative sign and the value, $1.919968,0.72541,0.93131$ and 0.118081 for, foreign direct investment, gross capital formation exchange rate and inflation rate respectively show that aggregate income adjusts to restore 86.4 percent of disequili- 
brium from the previous year to the current year.

Now, all the estimated coefficients of included variables are consistent with economic theory, which are, foreign direct investment, gross capital formation exchange rate and inflation rate positive elasticity with gross aggregate income. $\mathrm{R}^{2}$ is fairly straight-forward; it is the percentage of the response variable variation that is explained by a linear model in short run. $\mathrm{R}^{2}=0.971747$ and showing that the total variation of dependent variable is explained by explanatory variables at $97 \%$.

\subsection{Normality Test}

The result of normality test shows JACQE-BERA probability equal to 0.942053 which greater than critical probability of $1 \%, 5 \%$ and $10 \%$ respectively, $\mathrm{H}_{\mathrm{O}}$ is not rejected the residuals are normally distributed. The result of normality test is presented in Appendix Figure A1.

\subsection{Correlogram Squared Residuals}

The target of this test is to indicate if the model includes the stochastic problem. The no serial correlation assumption should be accepted in the choice of the model. There is serial autocorrelation when error of period $t$ influences the error of the following period $t+1$.

The probability of the errors in period $t$ should be independent of the probability of the occurrence of error $\mathrm{s}$ in period $t+1$. The results of Correlogram presented in Appendix Table A5 shows that there is no serial correlation of residuals up to 12 lag due to the probability, most of the probabilities are greater than $10 \%$ critical probability.

\subsection{Ramsey Reset Test}

Referring to the above results, the probability of the lag likelihood ratio is equal to 0.0003 less to critical value of $10 \%, \mathrm{H}_{\mathrm{O}}$ is not rejected, and the model is correctly specified.

\subsection{Stability Test}

The stability test is done by the CUSUM TEST. This test is based on the cumulative sum of recursive residuals. The cumulative sum is plotted with the $5 \%$ critical lines. The instability parameter occurs when the cumulative sum lay outside the area between two critical lines.

Basing on above outcome the parameters are stable due to the cumulative sum lay in critical lines at $5 \%$ significance. The econometricians considered this test as the master; it helps the prediction or forecast to take place at given model. The perfect set of diagnostic results, due to above performed tests, for researcher it is reasonable to conclude that the residuals do satisfy the assumptions of the classical normal linear regression model. 
Table 1. Ramsey reset test.

Ramsey Reset Test

Equation: EQ01

Specification: GDP C LOG_FDI LOG_GROSS_CAP LOG_EXCH

INFLATION_RATE

Omitted Variables: Squares of Fitted Values

\begin{tabular}{rccc}
\hline & Value & df & Probability \\
\hline T-statistic & 3.586940 & 22 & 0.0016 \\
F-statistic & 12.86614 & $(1,22)$ & 0.0016 \\
Likelihood ratio & 12.89326 & 1 & 0.0003 \\
\hline
\end{tabular}

Source: E-views 9.

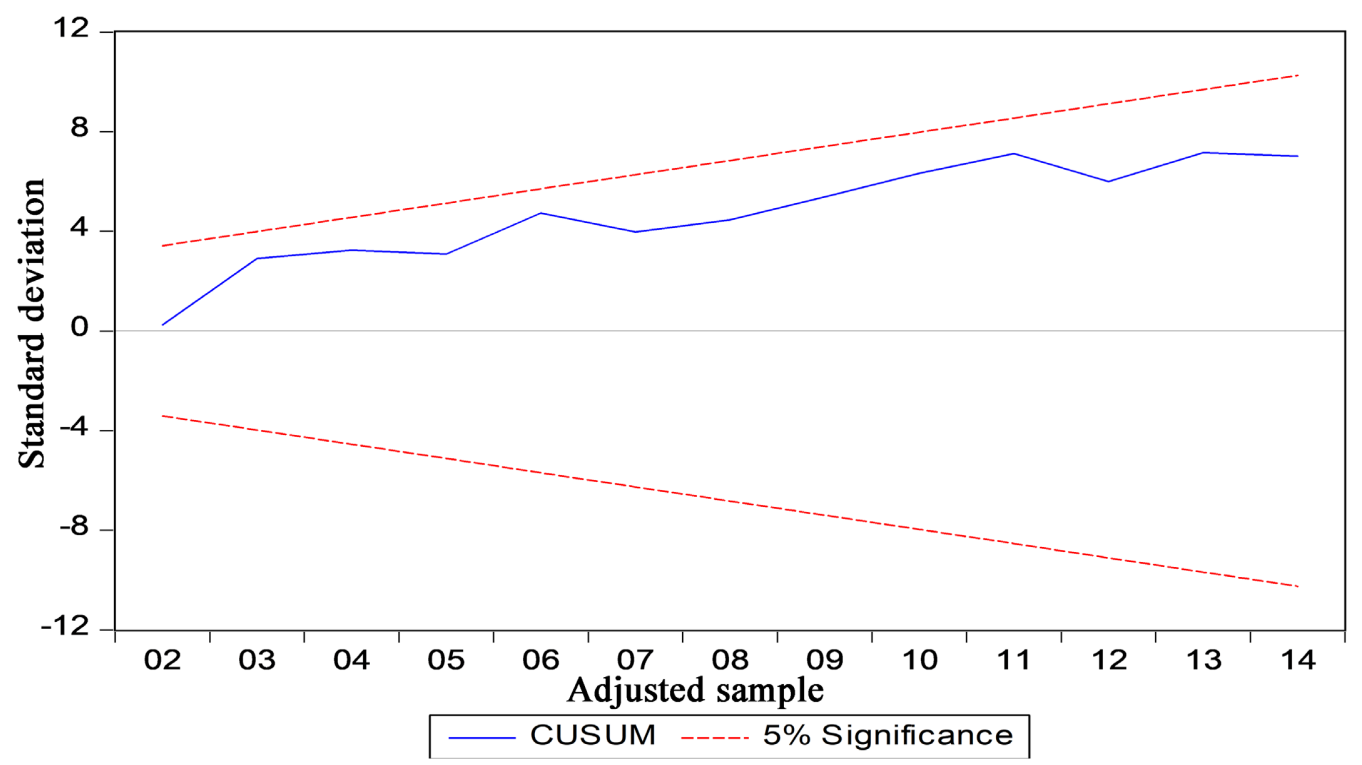

Source: E-views 9.

Figure 1. CUSUM test of parameter stability.

The stability tests, namely the Ramsey RESET test (Table 1) and the CUSUM test (Figure 1) suggests that there is no specification error and parameters are stable.

\section{Summaries and Conclusions}

More successful developing countries owe much of their success to having been able to maintain the high rate of GDP growth. A country's capital formation and foreign direct investment are important determinants of economic growth.

They do react to some macroeconomic variables and to knowing those variables can help a country to improve its competitiveness within the region and international level. The main target of this study was an attempt to analyze empirically the determinants of GDP growth in Rwanda during 1990-2017 using econometrics. This research used secondary data, collected from the reports of 
the Ministry of Finance and Economic Planning, National Bank of Rwanda. The researcher's preoccupation was to analyze, and test the contribution of foreign direct investment and gross capital formation in Rwanda; in order to arrive at the econometric results, many of the tests were to know stationarity where series like GDP growth, foreign direct investment and inflation rate were stationary at a level whereas foreign direct investment and exchange rate became stationary after first difference. In addition, there is a cointegrating relationship of the variables in the model which is statistically significant at the $1 \%$ level. The long-run and short-run models showed that capital formation, foreign direct investment, inflation rate and exchange rate have a significant impact on GDP growth in shortrun as well as in the long-run. The diagnostic tests showed that the model does satisfy the assumptions of the classical normal linear regression model. The stability tests, namely the Ramsey RESET test and the CUSUM test respectively suggest that there is no misspecification error and that parameters are stable.

$\mathrm{R}$-square, the overall measure of goodness of fit indicates that the explanatory variables included in the above model explain $89.3 \%$ of the variation of the dependent variable (GDP growth) for the long-run regression model and $97 \%$ for the error correction model.

The error correction model shows that the speed back to equilibrium is $86.4 \%$ that is when a shock happens in the previous period it decreases by $86 \%$ in the current period. This indicates that there is a significant short-run relationship as it was shown by the coefficients of the error correction model which are significant.

The model was precisely good because all classical assumption was verified through diagnostic tests. Based on the above findings, the second hypothesis that there is a long-run and short-run relationship between capital formation, foreign direct investment and aggregate income in Rwanda is approved and confirmed.

This study examined the determinants of economic growth in Rwanda from 1990-2017. The long-run results indicated that capital formation and foreign direct investment exert a positive and significant effect on aggregate income. With increased capital formation, it can be assured that such public investments crowd in private sector investment and increase the gross domestic product of the Rwandan economy in the long-run. Fiscal space must be created in the government budget to finance greater public investments. This can arise by way of broadening the tax base, reducing exemptions and simplifying the tax system so as to include elements in the informal sector not currently captured by the tax system.

The link between domestic credit and private investment can be potentially exploited so as to stimulate increased capital formation. For the future study, the researcher should consider how much the state should increase the government expenses and revenues so that social welfare won't be affected.

\section{Conflicts of Interest}

The author declares no conflicts of interest regarding the publication of this paper. 


\section{References}

Adamu, P. A., \& Oriakhi, D. E. (2013). The Impact of Foreign Direct Investment on Economic Growth in the Economic Community of West Africa States. African Journal of Economic Policy, 20, 89-114.

Barro, R. J. (1990). Government Spending in a Simple Model of Endogeneous Growth. Journal of Political Economy, 98, S103-S125.

Boopen, S., \& Khadaroo, A. J. (2008). Transportation Capital and Private Capital Formation in Mauritius: Testing the Substitutability and Complementarity Hypotheses. University of Mauritius.

Boskin, M. J., \& Lau, L. J. (1990). Post-War Economic Growth in the Group of Five Countries: A New Analysis, California. Centre for Economic Policy Research Publication.

Eltis, W. (2000). The Classical Theory of Economic Growth. Palgrave Macmillan.

Mallakh, R. (1969). The Economics of Rapid Growth: Libya. The Middle East Journal, 23, 308-320.

Mankiw, N. G. (2003). Macroeconomics (Vol. 41). Worth Publishers.

Ministry of Finance and Economic Planning (MINECOFIN) (2012). Rwanda Vision 2020. https://www.minecofin.gov.rw/reports?tx filelist filelist $\% 5 B$ action $\% 5 \mathrm{D}=$ list\&tx filelist filel ist $\% 5$ Bcontroller $\% 5 \mathrm{D}=$ File\&tx filelist filelist $\% 5 \mathrm{Bpath} \% 5 \mathrm{D}=\% 2 \mathrm{Fuser}$ upload\%2FMinecofi n\%2FPublications\%2FSTRATEGIES\%2FVision 2020\%2F\&cHash=0e0cb1929dab10048f83 35c554821cc4

Ministry of Finance and Economic Planning (MINECOFIN) (2017). National Strategy for Transformation.

https://www.minecofin.gov.rw/reports?tx filelist filelist $\% 5 B$ action $\% 5 \mathrm{D}=$ list\&tx filelist filel ist $\% 5 \mathrm{Bcontroller} \% 5 \mathrm{D}=$ File\&tx filelist filelist $\% 5 \mathrm{Bpath} \% 5 \mathrm{D}=\% 2 \mathrm{Fuser}$ upload\%2FMinecofi n\%2FPublications\%2FSTRATEGIES\%2FNST1\%2F\&cHash=b0bd9e867dacabdb56cff5cc0a $\underline{71 \mathrm{bd} 0 \mathrm{a}}$

Ministry of Finance and Economic Planning (MINECOFIN) (2020). Rwanda Vision 2050. https://www.minecofin.gov.rw/fileadmin/user_upload/Minecofin/Publications/STRAT EGIES/Vision 2050/Kinyarwanda-Vision 2050 Full version-Web.pdf

Ndugbu, M. O., Duruechi, A. H., \& Ojegbe, J. S. (2017). Macroeconomic Policy Variables and Foreign Direct Investment in Nigeria. IIARD International Journal of Banking and Finance Research, 3, 112-136.

NISR (2018). Gross Domestic Product for the Year 2021/2018. National Institute of Statistics of Rwanda.

Simbi, E. (2019). Trade Deficit, Foreign Direct Investment and Economic Growth "Evidences from Rwanda" (2000Q1-2015Q4). International Journal of Scientific Research and Engineering Development, 2, 840-859.

Tayebwa, B. M., Mugasi, S. K., \& Sabiiti, E. N., (2000). The Economic Implications of Bush Encroachment on Livestock Farming in Rangelands of Uganda. African Journal of Range and Forage Science, 17, 64-69. https://doi.org/10.2989/10220110009485741 


\section{Appendixes}

Table A1. Stationarity test.

\begin{tabular}{|c|c|c|c|c|c|}
\hline \multirow{2}{*}{ Variables } & \multicolumn{4}{|c|}{ ADF Test } & \multirow{2}{*}{ Decision } \\
\hline & Model & $\mathrm{ADF}_{\text {calculated }}$ & $\mathrm{ADF}_{\text {critical }}$ & Probability & \\
\hline GDP & Intercept & -6.840049 & $\begin{array}{c}\text { 1\% level: }-3.699871 \\
5 \% \text { level: }-2.976263 \\
10 \% \text { level: }-2.627420\end{array}$ & $0.0000^{\star * *}$ & $\begin{array}{l}\text { GDP is } \\
\text { stationary } \\
\text { at level }\end{array}$ \\
\hline FDI & $\begin{array}{l}\text { Trend and } \\
\text { Intercept }\end{array}$ & -10.37356 & $\begin{array}{c}\text { 1\% level: }-4.356068 \\
\text { 5\% level: }-3.595026 \\
\text { 10\% level: }-3.233456\end{array}$ & $0.0000^{* * *}$ & $\begin{array}{l}\text { FDI is } \\
\text { stationary } \\
\text { at level }\end{array}$ \\
\hline $\begin{array}{c}\text { Gross } \\
\text { capital } \\
\text { formation }\end{array}$ & $\begin{array}{c}\text { Trend and } \\
\text { intercept }\end{array}$ & -5.536543 & $\begin{array}{c}\text { 1\% level: }-4.374307 \\
5 \% \text { level: }-3.603202 \\
\text { 10\% level: }-3.238054\end{array}$ & $0.0007^{\star * \star}$ & $\begin{array}{l}\text { Gross capital } \\
\text { formation is } \\
\text { stationary at } \\
1^{\text {st }} \text { difference }\end{array}$ \\
\hline $\begin{array}{l}\text { Inflation } \\
\text { rate }\end{array}$ & $\begin{array}{l}\text { Tend and } \\
\text { Intercept }\end{array}$ & -4.272901 & $\begin{array}{c}\text { 1\% level: }-4.467895 \\
\text { 5\% level: }-3.644963 \\
\text { 10\% level: }-3.261452\end{array}$ & $0.0148^{\star *}$ & $\begin{array}{c}\text { Inflation rate } \\
\text { is stationary at } \\
\text { level }\end{array}$ \\
\hline $\begin{array}{c}\text { Exchange } \\
\text { rate }\end{array}$ & $\begin{array}{l}\text { Tend and } \\
\text { Intercept }\end{array}$ & -3.756473 & $\begin{array}{c}\text { 1\% level: }-4.356068 \\
5 \% \text { level: }-3.595026 \\
\text { 10\% level: }-3.233456\end{array}$ & $0.0361^{\star *}$ & $\begin{array}{c}\text { Exchange rate } \\
\text { is stationary at } \\
1^{\text {st }} \text { difference }\end{array}$ \\
\hline
\end{tabular}

Source: designed by the researcher from E-Views 9 results. Hint of conclusion: $\left.{ }^{*}\right)$ : Stationary at the level of $10 \%$; $\left(^{* *}\right)$ : Stationary at the level of $5 \%$; and $\left({ }^{* *}\right)$ : Stationary at the level of $1 \%$

Table A2. Cointegration/Engle granger test.

\begin{tabular}{|c|c|c|c|c|}
\hline \multirow{2}{*}{ Variable } & \multicolumn{3}{|c|}{ Engle Granger (EG) Test } & \multirow{2}{*}{ Decision } \\
\hline & Model $\mathrm{EG}_{\text {calculated }}$ & $\mathrm{EG}_{\text {critical }}$ & Probability & \\
\hline Residual & None -6.535957 & $\begin{array}{c}\text { 1\% level: }-2.653401 \\
5 \% \text { level: }-1.953858 \\
\text { 10\% level: }-1.609571\end{array}$ & $0.0000^{\star * *}$ & $\begin{array}{l}\text { There is cointegrating } \\
\text { relationship of } \\
\text { variables in the model }\end{array}$ \\
\hline
\end{tabular}


Table A3. Long-run regression result.

\begin{tabular}{|c|c|c|c|c|}
\hline $\begin{array}{l}\text { Dependent Variable: GD } \\
\text { Method: Least Squares } \\
\text { Date: 04/27/19 Time: } 10 \\
\text { Sample: } 19902017 \\
\text { Included Observations: } 2\end{array}$ & & & & \\
\hline Variable & Coefficient & Std. Error & t-Statistic & Prob. \\
\hline $\mathrm{C}$ & 350.1624 & 92.12033 & 3.801141 & 0.0009 \\
\hline LOG_FDI & 0.597754 & 1.401849 & 6.133153 & 0.0000 \\
\hline LOG_GROSS_CAP & 2.27776 & 4.685001 & -4.328231 & 0.0002 \\
\hline LOG_EXCH & 0.501893 & 3.951909 & 2.151338 & 0.0422 \\
\hline INFLATION_RATE & 0.169646 & 0.075525 & 2.246232 & 0.0422 \\
\hline R-squared & 0.893158 & Mean de & dent var & 3.548123 \\
\hline Adjusted R-squared & 0.639794 & S.D. det & lent var & 12.36429 \\
\hline S.E. of regression & 7.420697 & Akaike i & criterion & 7.006856 \\
\hline Sum squared resid & 1266.535 & Schwar & iterion & 7.244749 \\
\hline Log likelihood & -93.09598 & Hannan- & nn criter. & 7.079582 \\
\hline F-statistic & 12.98926 & Durbin- & tson stat & 2.236311 \\
\hline Prob (F-statistic) & 0.000011 & & & \\
\hline
\end{tabular}

Table A4. Error correction result.

Dependent Variable: DGDP

Method: Least Squares

Date: 04/28/19 Time: 15:14

Sample (Adjusted): 19912017

Included Observations: 27 after Adjustments

\begin{tabular}{ccccc}
\hline Variable & Coefficient & Std. Error & t-Statistic & Prob. \\
\hline C & -5.518532 & 1.148788 & -4.803788 & 0.0001 \\
DLOG_FDI & 1.919968 & 1.048087 & -1.831879 & 0.0812 \\
DLOG_GROSS_CAP & 0.72541 & 5.418497 & 6.224126 & 0.0000 \\
DLOG_EXCH & 0.93131 & 8.100145 & 4.559339 & 0.0002 \\
DINF_RATE & 0.118081 & 0.044099 & 2.677622 & 0.0141 \\
U (-1) & -0.864952 & 0.117590 & -7.355632 & 0.0000 \\
R-squared & 0.971747 & Mean dependent var & 0.231052 \\
Adjusted R-squared & 0.965020 & S.D. dependent var & 20.26784 \\
S.E. of regression & 3.790705 & Akaike info criterion & 5.696111 \\
Sum squared resid & 301.7584 & Schwarz criterion & 5.984075 \\
Log likelihood & -70.89750 & Hannan-Quinn criter. & 5.781738 \\
F-statistic & 144.4546 & Durbin-Watson stat & 1.693168 \\
Prob (F-statistic) & 0.000000 & &
\end{tabular}




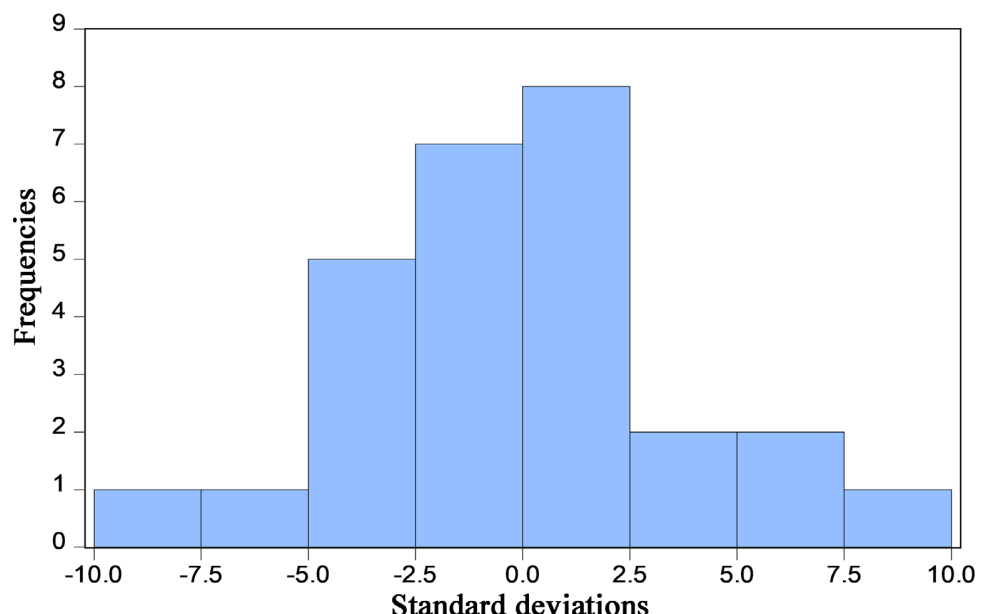

Series: Residuals

Sample 19912017

Observations 27

Mean

$2.64 \mathrm{e}-13$

Median $-0.065791$

Maximum

8.680219

Minimum

$-7.508250$

Std. Dev.

3.807175

Skewness $\quad 0.159516$

Kurtosis

2.934110

Jarque-Bera

0.119388

Probability

0.942053

Source: E-views 9.

Figure A1. Normality test.

Table A5. Correlogram.

Date: 04/28/19 Time: 16:31

Sample: 19902017

Included Observations: 28

\begin{tabular}{|c|c|c|c|c|c|c|}
\hline Autocorrelation & Partial Correlation & & AC & PAC & Q-Stat & Prob \\
\hline.$*|\cdot|$ &.$* *|\cdot|$ & 1 & -0.299 & -0.299 & 2.7743 & 0.096 \\
\hline$\cdot{ }^{*} \cdot 1$ & $*^{* * 1} \cdot 1$ & 2 & -0.202 & -0.319 & 4.0868 & 0.130 \\
\hline$\cdot 1 \cdot 1$ & $\cdot{ }^{*}|\cdot|$ & 3 & 0.036 & -0.169 & 4.1316 & 0.248 \\
\hline$\cdot|\cdot|$ & $\cdot{ }^{*} \cdot 1$ & 4 & 0.051 & -0.077 & 4.2214 & 0.377 \\
\hline$\cdot 1 \cdot 1$ & $\cdot 1 \cdot 1$ & 5 & 0.034 & 0.011 & 4.2637 & 0.512 \\
\hline$\cdot 1 \cdot 1$ & $\cdot|\cdot|$ & 6 & 0.025 & 0.073 & 4.2870 & 0.638 \\
\hline$\cdot 1 \cdot 1$ & $\cdot 1^{*} \cdot \mid$ & 7 & 0.025 & 0.117 & 4.3127 & 0.743 \\
\hline$\cdot{ }^{*} \cdot 1$ & $\cdot|\cdot|$ & 8 & -0.101 & -0.019 & 4.7437 & 0.785 \\
\hline$\cdot 1 \cdot 1$ & $\cdot 1 \cdot 1$ & 9 & 0.062 & 0.048 & 4.9129 & 0.842 \\
\hline$\cdot 1 \cdot 1$ & .1. & 10 & 0.031 & 0.031 & 4.9586 & 0.894 \\
\hline I. 1 & .1. & 11 & -0.035 & -0.007 & 5.0200 & 0.930 \\
\hline$|\cdot|$ & $1 \cdot 1$ & 12 & -0.035 & -0.050 & 5.0826 & 0.955 \\
\hline
\end{tabular}

Source: E-views 9. 